\title{
ANALISIS FAKTOR INTENSI KEWIRAUSAHAAN TENAGA KERJA WANITA PURNA GUNUNG KIDUL UNTUK KEMANDIRIAN
}

\author{
Kusuma Chandra Kirana \\ kusumack@ustjogja.ac.id \\ UST-Jogja \\ Kusrini \\ M. Idris Purwanto \\ Universitas Amikom Yogyakarta
}

\begin{abstract}
The Objective the research is, to digging ability and willingness to behave economy of the former maids Gunug Kidul Regency Yogyakarta, so as to provide a way to alleviate poverty in Gunung Kidul in Yogyakarta with a cash endowment fund utilization. Gunung Kidul is part of the territory of Yogyakarta Province which has a vast coastal areas. Poverty that occurs with low education triggers Gunung Kidul resident working as domestic servants both domestically and abroad. Gunung Kidul District, also known as the highest scorer of migrant workers in the province. The method in this study using a sampling method. This research is a quantitative study, samples were taken from the existing population research subjects. The data used in this study are primary data and secondary data that are complementary. The subjects of this research is a former migrant worker in Gunung Kidul, Yogyakarta. Technique data retrieval is done through questionnaires, interviews and documentation. Furthermore, the data were analyzed using SPSS software for Windows 15.00. The results of this study, namely, there are fairly strong partial correlation of personality variables, environment and demographics to intention entrepreneurship former migrant worker. Of the three variables greatest correlation exist in the environment variable.
\end{abstract}

Key words: personality, environment, demographi, intention, migrant worker

\begin{abstract}
ABSTRAK
Penelitian bertujuan untuk, menganalisis pengaruh kepribadian, lingkungan dan demografi para TKW purna di Kabupaten Gunug Kidul Yogyakarta, dengan mengetahui besarnya pengaruh dari variabel yang diteliti, diharapkan dapat memberikan saran yang tepat untuk membantu mengentaskan kemiskinan di Gunung Kidul Yogyakarta. Metode dalam penelitian ini menggunakan metode sampling. Penelitian ini merupakan penelitian kuantitatif, sampel diambil dari populasi subyek penelitian yang ada. Sumber data yang digunakan dalam penelitian ini adalah data primer dan data sekunder yang sifatnya sebagai pelengkap. Subyek penelitian dalam penelitian ini adalah mantan TKW di Kabupaten Gunung Kidul Yogyakarta. Teknik pengambilan data dilakukan dengan melalui kuesioner, wawancara dan dokumentasi. Hasil dari penelitian ini yaitu, terdapat korelasi parsial dari variabel kepribadian, lingkungan dan demografi terhadap Intensi kewirausahaan TKW purna, diantara ketiga varibel, lingkungan memiliki pengaruh yang paling kuat terhadap intensi. Secara simultan menunjukkan adanya korelasi dari variabel kepribadian, lingkungan dan demografi terhadap intensi kewirausahaan TKW purna di Gunung Kidul. Kontribusi dari ketiga variabel terhadap intensi sebesar 23,3\%, sedang sisanya dipengaruhi oleh variabel lain. Pengujian hipotesis simultan menunjukkan bahwa variabel lingkungan, variabel kepribadian, dan variabel demografi secara bersamasama berpengaruh terhadap intensi kewirausahaan TKW purna di Gunung Kidul.
\end{abstract}

Kata kunci : intensi, kewirausahaan, TKW, Gunung Kidul 


\section{PENDAHULUAN}

Kabupaten Gunung Kidul merupakan bagian wilayah dari Provinsi Daerah Istimewa Yogyakarta yang memiliki daerah pesisir pantai yang luas. Kondisi tanah yang tandus membuat Gunung Kidul dinyatakan sebagai salah satu wilayah dengan angka kemiskinan yang tinggi. Kemiskinan yang terjadi dengan pendidikan rendah menjadi pemicu penduduk Gunung Kidul bekerja sebagai Pembantu Rumah Tangga baik di dalam negeri maupun di luar negeri. Gunung Kidul juga dikenal sebagai Kabupaten pencetak buruh migran tertinggi di Yogyakarta. Seperti kebanyakan TKW (Tenaga Kerja Wanita) yang bekerja di luar negeri motif utama menjadi TKW ke luar negeri adalah ekonomi. Kemiskinan dan pengangguran telah membuat para TKW nekat berangkat mengadu nasib. Disebut nekat, karena sebagian besar mereka tidak memiliki bekal pengetahuan yang memadai untuk bisa bekerja di luar negeri. Sebagian dari mereka memang berhasil mencapai pendapatan yang signifikan untuk membangun kehidupan ekonomi keluarganya, namun tidak sedikit diantara mereka yang gagal. Terlepas dari keberhasilan para TKW ini, mereka mempunyai resiko yang sama besar, yaitu penyiksaan dan penganiayaan. Berdasarkan data yang ada di Dinsoskertrans Gunung Kidul, setidaknya terdapat sebanyak 373 kasus yang menimpa TKW dari Gunung Kidul, dan terdapat kecenderungan meningkat pada tiap tahun nya. Situasi ini tentu saja harus menjadi perhatian serius tidak hanya oleh pemerintah, namun juga oleh para kaum cendekiawan dan tokoh masyarakat.

TKW di Gunung Kidul, dengan berbagai daya tarik dan permasalahan yang mengikutinya, telah mendorong pemerintah Daerah Istimewa Yogyakarta (DIY), untuk mengambil tindakan tegas, dengan mengeluarkan Perda, yang membatasi dan bahkan melarang adanya pengiriman TKW ke luar negeri. Adanya arahan dari Gubernur DIY yang melarang pengiriman TKI informal ke luar negeri sejak tahun 2014 lalu, terbukti efektif. Hal ini ditekankan oleh kepala Dinsosnakertrans (Dinas Sosial Tenaga Kerja dan Transmigrasi) bahwa, sudah sejak 2 tahun yang lalu, Gunung Kidul tidak lagi membuka perijinan TKW ke luar negeri. Berdasarkan data yang ada pada Dinsoskertrans Gunung Kidul, Tenaga Kerja Indonesia (TKI) selama ini tergolong dalam 2 kategori, yaitu TKI formal dan TKI informal. TKI formal, yaitu para tenaga kerja yang bekerja di luar negeri, yang merupakan tenaga ahli. Mereka tercatat bekerja di suatu organisasi bisnis di luar negeri, sebagai tenaga ahli (tenaga medis, mekanik, pendidik, dan lain-lain), sedangkan TKI informal adalah mereka yang bekerja di luar negeri, yang mayoritas bekerja sebagai buruh rumah tangga. Para TKI informal ini mayoritas adalah wanita, sehingga seringkali disebut sebagai Tenaga Kerja Wanita (TKW). Berdasarkan data yang diperoleh dari dinas sosial, saat ini jumlah TKW di Gunung kidul sebanyak 6.873 orang. Dari jumlah tersebut, tercatat sudah purna sebanyak 400 orang dan semuanya adalah wanita. Para TKW informal yang dimaksud rata-rata bekerja di luar negeri sebagai buruh rumah tangga, selama lebih dari 5 tahun. Adapun hasil yang mereka dapatkan selama ini lebih banyak dipergunakan untuk tujuan konsumtif. Itulah sebabnya mengapa setelah mereka tidak mampu lagi bekerja karena usia, mereka kembali miskin. Fenomena ini banyak terjadi pada para TKW di seluruh Indonesia. Hanya sedikit diantara mereka yang benar-benar berhasil mencapai kemandirian ekonomi. Berlatar belakang situasi tersebut, maka peneliti membuat penelitian dengan tujuan untuk memberikan hasil yang dapat dijadikan dasar bagi pemerintah dan/atau pihak yang membutuhkan sehingga dapat dijadikan dasar pengambilan kebijakan strategis mengenai kemandirian ekonomi bagi para TKW khususnya di wilayah Gunung Kidul, agar mampu menjadi tuan di negeri sendiri.

Model pemberdayaan ekonomi, para mantan TKW perlu dibuat, sebagai arah tercapainya tujuan pemerintah khususnya 
pemerintah daerah Gunung Kidul, dalam mengurangi angka kemiskinan. Hal ini tentu saja akan dengan mudah terwujud, jika ada sinergi yang baik antar dinas terkait. Salah satu upaya dalam memberdayakan masyarakat miskin di Gunung Kidul yang telah dilakukan adalah dengan memberikan pembelajaran mengenai kewirausahaan. Banyak pelatihan kewirausahaan yang telah dilakukan, namun pencapaiannya dirasa belum optimal. Salah satu kendala yang dihadapi dalam membentuk jiwa kewirausahaan di Gunung Kidul, karena penyelenggara program, tidak menganggap penting adanya forum, untuk melihat dengan teliti apa yang dibutuhkan masyarakat, sehingga implementasi pelatihan kewirausahaan pada masyarakat menjadi salah sasaran. Yang dimaksud salah sasaran yaitu, banyak peserta pelatihan yang gagal atau tidak mampu mengelola usaha dengan baik.

Berpijak pada kegagalan tersebut, maka peneliti mengawali pembentukan model kemandirian ekonomi para mantan TKW di Gunung Kidul dengan menganalisis faktor yang diduga mempengaruhi intensi para TKW purna di Gunung Kidul pada Kewirausahaan. Harapannya, dengan mengetahui faktor-faktor yang berpengaruh terhadap intensi kewirausahaan maka dapat menghasilkan model strategi yang tepat, seperti yang dilakukan oleh Budiati et al. (2012), yang melakukan penelitian serupa dengan obyek adalah mahasiswa, yang mana diketahui bahwa minat berwirausaha berpengaruh pada kesuksesan usaha. Lebih lanjut, tujuan dari penelitian ini adalah, ingin mengetahui dan menganalisis faktor yang mempengaruhi intensi kewirausahaan para mantan TKW di Gunung Kidul Yogyakarta.

\section{TINJAUAN TEORETIS}

\section{Definisi Kemiskinan}

Kemiskinan secara epistimologi, adalah suatu keadaan dimana individu tidak memiliki kemampuan secara ekonomi untuk memenuhi kebutuhannya. Selama ini metode umum yang digunakan untuk menghitung jumlah penduduk miskin adalah metode Head Count Index (HDI). Menurut metode ini, penduduk yang dikategorikan miskin adalah mereka yang berada di bawah suatu batas yang disebut dengan garis kemiskinan. Garis kemiskinan yang dimaksud yaitu nilai rupiah yang harus dikeluarkan seseorang untuk memenuhi kebutuhan hidup minimumnya, baik itu untuk makanan, minuman, perumahan, kesehatan, pendidikan dan transportasi.

Seseorang dikatakan hidup sehat apabila telah dapat memenuhi energi minimal 2.100 kilo kalori per hari (Standar BPS). Berdasarkan ketentuan BPS tersebut, maka batas kemiskinan untuk makanan adalah nilai rupiah yang dikeluarkan seseorang untuk dapat memenuhi kebutuhan hidup minimal 2.100 kilo kalori per hari yang didasarkan atas konsumsi makanan dan penduduk kelas marginal.

\section{Pengertian Kemandirian Ekonomi}

Suatu situasi dimana masyarakat mampu memenuhi kebutuhan ekonomi secara mandiri melalui kegiatan produksi dalam rangka mensejahterakan diri, dan tidak tergantung kepada orang lain (Gamal, 2007). Oleh karena itu, kemandirian ekonomi yang dimaksud dalam penelitian ini adalah kemampuan para mantan TKW di Gunung Kidul dalam memenuhi kebutuhan ekonomi nya secara mandiri tanpa dominasi pihak lain.

\section{Pemberdayaan Masyarakat Miskin Daerah Istimewa Yogyakarta}

Program yang digagas dan dijalankan oleh pemerintah provinsi Daerah Istimewa Yogyakarta (DIY) ini dimulai dari tahun 2010 dan berakhir tahun 2011. Tujuan dari program adalah; meningkatkan fungsi sarana atau prasarana kebutuhan masyarakat, meningkatkan kualitas rumah tangga dan sanitasi rumah tangga miskin, dan pemberdayaan masyarakat secara aktif, terpadu dan gotong royong serta berkelanjutan.

Program ini mampu membangun berbagai sarana umum dan memberi kesadaran masyarakat untuk hidup sehat, namun pada 
implementasinya program ini belum mampu memberdayakan masyarakat miskin di DIY untuk memiliki kemandirian secara ekonomi.

\section{Program Pemberdayaan Potensi Desa}

Tujuan dari program yang dirancang oleh Bapenas ini adalah, mendorong terwujudnya kemandirian masyarakat desa melalui pengembangan potensi unggulan dan penguatan kelembagaan serta pemberdayaan kelompok masyarakat (Pokmas) Rumah Tangga Miskin. Program ini pada awalnya dirasa efektif mampu menemukan potensi unggulan daerah, namun implementasinya kurang efektif karena banyak masyarakat miskin yang tidak ikut berpartisipasi.

\section{PNPM Mandiri}

Program yang melibatkan salah satu Bank terbesar di Indonesia ini membantu masyarakat miskin untuk bisa berwiraswasta dengan memberi pinjaman lunak, namun pada implementasinya dirasa terlalu berbelit, sehingga banyak masyarakat miskin yang seharusnya lebih membutuhkan menjadi tidak tersentuh, program hanya berputar-putar pada masyarakat menengah dan akhirnya lebih mengarah pada orientasi keuntungan di sektor perbankan yang mengusungnya.

\section{Pengembangan SDM industri Kecil Menengah}

Program ini merupakan program dari disperindagkop, yang mana masyarakat miskin diberdayakan dengan memberi pelatihan berproduksi melalui industri kecil, namun program ini juga menjadi kurang efektif, karena tidak semua masyarakat miskin memiliki minat untuk terjun di bidang industri, terlebih lagi, jika kita melihat persentase angka kemiskinan yang ada, mereka lebih banyak berada di daerah pedesaan, yang notabene orientasi ekonominya adalah bertani bukan berindustri.

\section{Peran Intensi Kewirausahaan Dalam Menciptakan Usaha Baru}

Intensi kewirausahaan mencerminkan komitmen seseorang untuk memulai usaha baru dan merupakan isu sentral yang perlu diperhatikan dalam memahami proses kewirausahaan dalam pendirian usaha baru (Krueger et al. 2000). Akhir-akhir ini semakin banyak dilakukan penelitian tentang intensi kewirausahaan, karena diyakini bahwa suatu intensi atau niat yang berkaitan dengan perilaku terbukti dapat menjadi cerminan dari perilaku yang sesungguhnya. Dalam teori planned behavior, Ajzen (2006) meyakini bahwa faktor-faktor seperti sikap dan norma subyektif akan membentuk niat seseorang dan selanjutnya secara langsung akan berpengaruh pada perilaku, oleh karena itu pemahaman tentang niat sese orang untuk berwirausaha (entrepreneurial intention) dapat mencerminkan kecenderungan orang untuk mendirikan usaha secara riil. Terdapat beberapa faktor yang mempengaruhi intensi kewirausahaan, antara lain: karakteristik kepribadian, karakteristik demografis, dan karakteristik lingkungan.

\section{Perumusan Hipotesis}

Pengaruh Kepribadian (Kep) terhadap Intensi Kewirausahaan (In Kew)

Penelitian terdahulu membuktikan bahwa faktor kepribadian seperti kebutuhan akan prestasi merupakan faktor yang secara signifikan mempengaruhi intensi kewirausahaan. Selain itu, juga disimpulkan bahwa secara umum terdapat perbedaan faktorfaktor yang mempengaruhi Intensi Kewirausahaan antara satu Negara dengan Negara lainnya, sedangkan hasil analisis statistik menunjukkan bahwa secara bersama-sama Kepribadian, Instrumen dan Demografi terbukti signifikan, menentukan Intensi Kewirausahaan (Indarti dan Rokhima. 2008). Dari uraian diatas dapat dirumuskan hipotesis penelitian sebagai berikut:

$\mathrm{H}_{1}$ : Kepribadian (Kep) berpengaruh terhadap Intensi Kewirausahaan (In Kew) 


\section{Pengaruh Lingkungan (Ling) terhadap Intensi Kewirausahaan (In Kew)}

Faktor lingkungan pada penelitian ini mengacu pada pendapat Kristiansen et al. (2003), yang menjelaskan bahwa jaringan sosial terdiri dari hubungan formal dan informal antara pelaku utama dan pendukung dalam satu lingkaran terkait dan menggambarkan jalur bagi wirausaha untuk mendapatkan akses kepada sumber daya yang diperlukan dalam pendirian, perkembangan, dan kesuksesan usaha.

Secara garis besar penelitian seputar intensi kewirausahaan dilakukan dengan melihat tiga faktor lingkungan yang berbeda-beda. Tiga faktor lingkungan yang dipercaya mempengaruhi wirausaha yaitu (1) akses kepada modal, seperti yang dikemukakan oleh Indarti dan Rokhima (2008) bahwa masalah dana dirasakan terutama oleh wirausaha ketika memulai usaha-usaha baru, setidaknya terjadi di negara-negara berkembang dengan dukungan lembagalembaga penyedia keuangan yang tidak begitu kuat. (2) ketersediaan informasi, merupakan faktor penting yang mendorong keinginan seseorang untuk membuka usaha. Hal ini membuktikan bahwa keinginan yang kuat untuk memperoleh informasi adalah salah satu karakter utama seorang wirausaha. (3) kualitas jaringan sosial, Morello et al. (2003) menyebutkan bahwa jaringan sosial mempengaruhi intensi kewirausahaan. Bagi wirausaha, jaringan merupakan alat mengurangi resiko dan biaya transaksi serta memperbaiki akses terhadap ide-ide bisnis, informasi dan modal. Dari uraian diatas dapat dirumuskan hipotesis penelitian sebagai berikut:

$\mathrm{H}_{2}$ : Lingkungan (Ling) berpengaruh terhadap Intensi Kewirausahaan (In Kew).

\section{Pengaruh Demografi (Dem) terhadap Intensi Kewirausahaan (In Kew)}

Faktor demografi seperti umur, jenis kelamin, latar belakang pendidikan dan pengalaman kerja seseorang juga menjadi faktor penentu intensi kewirausahaan. Dalam penelitian-penelitian tentang kewirausahaan terdahulu menunjukkan bahwa faktor-faktor demografis seperti jenis kelamin, umur, pendidikan, dan pengalaman bekerja seseorang berpengaruh terhadap keinginannya untuk menjadi seorang wirausaha. Cheraghi, M. dan T. Schott. 2015. Sementara itu, hasil penelitian Oosterbeek et al. (2008) menemukan bahwa wirausaha yang sukses memiliki kebutuhan akan kekuasaan (the need of power) yang tinggi untuk mengendalikan orang lain. Seorang wirausaha tahu apa yang mereka inginkan dan cara mempengaruhi orang lain untuk mencapai tujuannya. Oosterbeek et al. (2008) juga menemukan bahwa wirausaha yang sukses memiliki kebutuhan akan prestasi pada tingkat yang tinggi. Dari uraian diatas dapat dirumuskan hipotesis penelitian sebagai berikut:

H3 : Demografi (Dem) berpengaruh terhadap Intensi Kewirausahaan (In Kew)

\section{METODE PENELITIAN}

Pendekatan yang akan digunakan untuk penelitian ini adalah pendekatan penelitian kuantitatif. Populasi dalam penelitian ini adalah para Tenaga kerja wanita (TKW) purna di Kabupaten Gunung Kidul. Hal ini didasarkan pada teori planned behavior, Ajzen (2006) menyatakan bahwa faktor-faktor seperti sikap dan norma subyektif akan membentuk niat seseorang dan selanjutnya secara langsung akan berpengaruh pada perilaku, oleh karena itu pemahaman tentang niat seseorang untuk berwirausaha (entrepreneurial intention) dapat mencerminkan kecenderungan orang untuk mendirikan usaha secara riil.

Sampel dalam penelitian ini ditetapkan dengan ciri: TKW yang sudah pernah bekerja di luar negeri dan kembali ke Indonesia, namun masih terkategori miskin dengan kurun waktu minimal 1 tahun terhitung dari tanggal kepulangannya. Hal ini dimaksudkan agar TKW purna masih memiliki persepsi yang kuat mengenai apa yang di rasa- 
kan dan dialami selama masa perantauannya sehingga dapat meminimalisasi kemungkinan adanya bias karena sudah lupa terhadap pengalaman yang dirasakan dari negara dimana dia bekerja sebelumnya. Jumlah sampel yang diteliti adalah 135 orang, hal ini didasarkan pada pendapat dari Arikunto (2006) yang menyatakan bahwa apabila subjeknya kurang dari seratus, lebih baik diambil semua sehingga penelitiannya merupakan populasi, tetapi jika jumlah subjek besar, dapat diambil antara $10-15 \%$. Jumlah populasi TKW purna di Gunung Kidul adalah 400 orang, sehingga total sampel yang digunakan dalam penelitian ini sebanyak 135 orang dianggap cukup. Dari jumlah 135 orang TKW purna yang dijadikan sampel, tersebar di berbagai kecamatan di Gunung Kidul.

Pengambilan sampel adalah purposive sampling, yaitu sengaja sampel yang dipilih adalah subjek yang tidak hanya sebagai pelaku langsung akan tetapi juga memahami permasalahan penelitian yang menjadi fokus kerja peneliti (Ghozali, 2006). Sampel yang dipilih adalah TKW purna yang masih terkategori miskin pada wilayah yang akan diteliti. Teknik pengambilan data yang dilakukan dengan menggunakan kuesioner, wawancara dan dokumentasi. Selanjutnya data dianalisis menggunakan Software SPSS 15,00 for Windows. Penelitian ini merupakan penelitian kuantitatif dengan metode sampling, sampel diambil dari populasi subjek penelitian yang ada. Sumber data yang digunakan dalam penelitian ini adalah data primer yang merupakan data yang diambil langsung dari lapangan dan data sekunder yang sifatnya sebagai pelengkap. Lokasi penelitian adalah Kabupaten Gunung Kidul di Provinsi Daerah Istimewa Yogyakarta. Penelitian mulai dilaksanakan dari bulan Pebruari 2016. Adapun jangka waktu efektif penelitian ini kurang lebih 4 (empat) bulan.

\section{Definisi Operasional Variabel}

Variabel Intensi Kewirausahaan

Ajzen (2006) meyakini bahwa faktorfaktor seperti sikap dan norma subyektif akan membentuk niat seseorang dan selanjutnya secara langsung akan berpengaruh pada perilaku, oleh karena itu pemahaman tentang niat seseorang untuk berwirausaha (entrepreneurial intention) dapat mencerminkan kecenderungan orang untuk mendirikan usaha secara riil.

\section{Variabel Kepribadian (Kep)}

Kepribadian sebagai suatu sifat dan kecenderungan yang tetap (tidak berubahubah) yang menentukan persamaan dan perbedaan perilaku di masyarakat (Mc. Clelland (dalam Morello et al., 2003)). Dalam kehidupan masyarakat, banyak kebutuhan yang muncul dari kebudayaan yang ada di masyarakat tersebut. Suatu kebutuhan yang kuat dalam diri seseorang akan memotivasi orang tersebut untuk berperilaku yang mengarah pada pemenuhan kebutuhan tersebut. Selanjutnya, Amari dan Abbes, (2014) dalam penelitian yang dilakukannya diketahui bahwa faktor kepribadian memiliki pengaruh yang paling dominan terhadap Intensi Kewirausahaan individu.

Pendapat dari McClelland dan hasil penelitian dari Amari tersebut, turut mengilhami penelitian tentang intensi kewirausahaan para TKW purna di Gunung Kidul. TKW purna yang mempunyai intensi untuk berwirausaha, kemudian diberikan bekal pelatihan, pendidikan maupun stimulus seperti bantuan modal, informasi, dan jaringan sosial.

\section{Variabel Lingkungan (Ling)}

Lingkungan pada penelitian ini mengacu pada pendapat Kristiansen et al. (2003), yang menjelaskan bahwa jaringan sosial terdiri dari hubungan formal dan informal antara pelaku utama dan pendukung dalam satu lingkaran terkait dan menggambarkan jalur bagi wirausaha untuk mendapatkan akses kepada sumber daya yang diperlukan dalam pendirian, perkembangan, dan kesuksesan usaha. Secara garis besar penelitian seputar intensi kewirausahaan dilakukan dengan melihat tiga faktor lingkungan yang berbeda-beda. Tiga 
faktor lingkungan yang dipercaya mempengaruhi wirausaha yaitu (1) akses mereka kepada modal, pada umumnya seseorang yang memulai usaha akan merasakan adanya hambatan yang disebabkan tidak adanya dana atau modal. Hambatan terhadap akses atau ketersediaan modal ini sebenarnya juga dirasakan oleh wirausaha yang sudah lama berusaha, namun karena adanya hubungan dengan berbagai pemasok dan adanya jaringan sosial, mereka lebih mudah untuk mengatasi masalah modal. Menurut Aliasuddin, (2002) menyatakan bahwa nilai potensi zakat atas tabungan mampu memberikan modal usaha yang relatif besar untuk orang fakir miskin. (2) ketersediaan informasi, merupakan faktor penting yang mendorong keinginan seseorang untuk membuka usaha. Hal ini membuktikan bahwa keinginan yang kuat untuk memperoleh informasi adalah salah satu karakter utama seorang wirausaha. Pencarian informasi mengacu pada frekuensi kontak yang dibuat oleh seseorang dengan berbagai sumber informasi. Wirausaha seringkali dihadapkan pada situasi pengambilan keputusan dengan informasi yang tidak lengkap. Untuk membantu proses pengambilan keputusan, wirausaha mencari tambahan informasi. Proses pencarian informasi akan tergantung pada karakteristik seseorang, seperti tingkat pendidikan dan kualitas infrastruktur seperti media dan sistem telekomunikasi. (3) kualitas jaringan sosial yang harus dimiliki. Konsep dasar dari analisis jaringan sosial (social networking) adalah bagaimana seorang individu dapat terpengaruh di lingkungan sosial mereka dengan kejadian yang ada di lingkungan mereka. Menganut pada konsep ini, maka seseorang akan terpengaruh oleh lingkungan di mana mereka berada. Kristiansen et al. (2003) yang menjelaskan bahwa jaringan sosial terdiri dari hubungan formal dan informal antara pelaku utama dan pendukung dalam satu lingkaran terkait dan menggambarkan jalur bagi wirausaha untuk mendapatkan akses kepada sumber daya yang diperlukan dalam pendirian, perkembangan, dan kesuksesan usaha.

\section{Variabel Demografi}

Kamus Besar Bahasa Indonesia memberikan arti kata demografi sebagai ilmu yang memberikan uraian atau gambaran statistik mengenai suatu bangsa dilihat dari sudut sosial, politik, dan ilmu kependudukan. Faktor-faktor demografi tersebut akan mempengaruhi perilaku hidup seseorang, termasuk dalam berwirausaha. Variabel demografi pada penelitian ini diisi sesuai dengan fakta dari TKW yang ada, yang meliputi kecamatan tempat bermukim, umur, pendidikan terakhir, dan pengalaman berwirausaha.

Ketiga variabel independen dalam penelitian ini ditentukan dengan menggunakan skala Likert, dengan skala 1 sampai 5, dengan konversi nilai:

1 : Tidak ditekankan

2 : Sedikit ditekankan

3 : Cukup ditekankan

4 : Ditekankan

5 : Sangat ditekankan

\section{Model Penelitian}

Pada penelitian ini, model yang digunakan adalah sebagai berikut pada gambar 1. Berdasarkan gambar 1 tersebut, dapat dijelaskan sebagai berikut, dengan mengetahui kepribadian para TKW purna di Gunung Kidul, dan mengenali Lingkungan dimana mereka tinggal juga mengetahui demografi maka dapat diketahui variabel mana yang paling dominan mempengaruhi intensi kewirausahaan para TKW purna di Kabupaten Gunung Kidul, serta mengetahui pengaruh masing-masing variabel kepribadian, lingkungan, dan demografi terhadap intensi kewirausahaan.

\section{Tehnik analisis}

Dalam penelitian ini analisis data dilakukan secara kuantitatif. Analisis yang dimaksud yaitu: 


\section{Analisis data kuantitatif}

Analisis data kuantitatif adalah analisis yang digunakan terhadap data yang berwujud angka-angka dan cara pembahasannya dengan uji statistik.
Analisis statistik yang digunakan dalam penelitian ini adalah analisis regresi berganda. Adapun tahap-tahap analisis kuantitatif yang digunakan dalam penelitian ini adalah sebagai berikut:

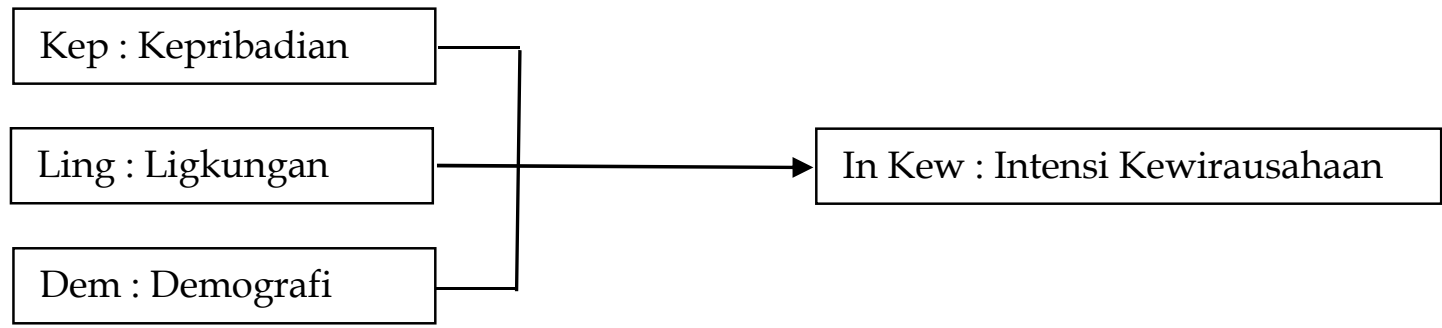

Gambar 1

Sumber : Data Penelitian

\section{Model Penelitian}

\section{Uji Validitas}

Uji Validitas digunakan untuk mengukur sah atau valid tidaknya suatu kuesioner. Suatu kuesioner dikatakan valid jika pertanyaan pada kuesioner mampu untuk mengungkapkan sesuatu yang akan diukur oleh kuesioner tersebut (Ghozali, 2006). Uji validitas dilakukan dengan mengkorelasikan antara skor yang diperoleh masingmasing pertanyaan dengan skor total (item total correlation). Skor total adalah skor yang diperoleh dari hasil penjumlahan semua skor pertanyaan. Uji validitas menguji apakah pertanyaan pada suatu kuesioner mampu untuk mengungkapkan sesuatu yang akan diukur untuk kuesioner tersebut. Dengan menggunakan program SPSS, uji validitas dilakukan dengan product moment pearson, yakni dengan mencari nilai faktor loading. Apabila faktor loading lebih dari 0,4 $(>0,4)$ maka pertanyaan atau pernyataan tersebut valid.

\section{Uji Reliabilitas}

Uji reliabilitas merupakan salah satu cara yang dapat dilakukan untuk menguji sejauh mana pengukuran memberikan hasil yang relatif stabil bila dilakukan pengukuran kembali. Suatu kuesioner dikatakan reliabel atau handal jika jawaban seseorang terhadap pertanyaan adalah konsisten atau stabil dari waktu ke waktu. Hasil uji relia- bilitas akan menentukan apakah alat ukur dapat dipercaya (reliabel) atau tidak. Uji reliabilitas dilakukan dengan menggunakan program SPSS dengan mencari nilai koefisien reliabilitas (alpha). Apabila Cronbach alpha $>0,6$ dan nilainya positif, berarti variabel yang diukur bersifat reliabel.

\section{Uji Asumsi Klasik \\ Uji Multikolinearitas}

Uji asumsi ini bertujuan untuk menguji model regresi ditemukan adanya korelasi antar variabel bebas. Jika ada korelasi, maka terdapat problem multikolinearitas. Pedoman suatu model regresi yang bebas multikolinearitas, yaitu mempunyai angka tolerance mendekati angka 1 dan mempunyai nilai VIF (variance inflation factor) disekitar angka 1 .

\section{Uji Heteroskedastisitas}

Uji heteroskedastisitas bertujuan menguji apakah dalam model regresi terjadi ketidaksamaan variance dari residual satu pengamatan ke pengamatan yang lain. Jika variance dari residual pengamatan ke pengamatan yang lain tetap, maka disebut homoskedastisitas dan jika berbeda heteroskedastisitas. Cara mendeteksinya adalah dengan cara melihat grafik plot antar nilai prediksi variabel terikat (ZPRED) dengan residualnya (SRESID). Deteksi ada tidaknya 
heteroskedastisitas dapat dilakukan dengan melihat ada tidaknya pola tertentu pada grafik scaterplot antar SRESID dan ZPRED. Jika ada pola tertentu seperti titik-titik yang ada membentuk pola tertentu yang teratur (bergelombang, melebar, kemudian menyempit), maka mengindikasikan telah terjadi heteroskedastisitas. Jika tidak ada pola yang jelas, serta titik-titik yang menyebar diatas dan di bawah angka nol pada sumbu Y, maka tidak terjadi heteroskedastisitas.

\section{Uji Normalitas}

Uji asumsi ini bertujuan untuk menguji sebuah model regresi, variabel dependen, variabel independen atau keduanya mempunyai distribusi normal atau tidak. Model regresi yang baik adalah distribusi normal atau mendekati normal. Jika data menyebar disekitar garis diagonal dan mengikuti arah garis diagonal, maka model regresi memenuhi normalitas. Jika data yang menyebar jauh dari garis diagonal dan mengikuti arah garis diagonal, maka regresi tidak memenuhi normalitas.

\section{Analisis Regresi Linier Berganda}

Analisis regresi linier berganda digunakan untuk menganalisis pengaruh beberapa variabel bebas atau variabel independen terhadap satu variabel tidak bebas atau variabel dependen secara bersamasama.
Dalam hubungan dengan penelitian ini, variabel independen meliputi Kepribadian (Kep), Lingkungan (Ling), dan Demografi (Dem), sedangkan variabel dependen adalah minat dan bakat kewirausahaan (In Kew). Persamaan regresi berganda dapat dituliskan sebagai berikut:

In Kew $=$ bo $+b_{1}$ Kep $+b_{2}$ Ling $+b_{3}$ Dem $+e$ Dimana,

In Kew : Intensi Kewirausahaan

Kep : Kepribadian

Ling : Lingkungan

Dem : Demografi

$b_{0} \quad$ : Konstanta

$b_{1}, b_{2}, b_{3}$ : Koefisien masing-masing faktor

e : Faktor pengganggu

\section{ANALISIS DAN PEMBAHASAN \\ Karakteristik Responden Berdasar Tempat Tinggal}

Populasi dalam penelitian ini adalah para mantan Tenaga Kerja Wanita yang tinggal di Kabupaten Gunung Kidul di Daerah Istimewa Yogyakarta. Dalam penelitian ini obyek penelitian dibatasi pada Kecamatan yang memiliki jumlah TKW terbanyak dibandingkan Kecamatan lainnya di Kabupaten Gunung Kidul.

Kecamatan yang dimaksud yaitu: Patuk, Playen, Tepus, Saptosari, Tepus, Smin, Nglipar, Ngawen, Ngunut dan Pojong. Untuk lebih jelasnya dapat dilihat pada Tabel 1 berikut:

Tabel 1

Analisis Responden Berdasarkan Tempat Tinggal

\begin{tabular}{llcccc}
\hline \hline & & Frequency & Percent & Valid Percent & Cumulative Percent \\
\hline Valid & Patuk & 35 & 23.5 & 23.5 & 23.5 \\
& Playen & 39 & 26.2 & 26.2 & 49.7 \\
& Saptosari & 11 & 7.4 & 7.4 & 57.0 \\
& Tepus & 19 & 12.8 & 12.8 & 69.8 \\
Semin & 12 & 8.1 & 8.1 & 77.9 \\
& Nglipar & 13 & 8.7 & 8.7 & 86.6 \\
Ngawen & 14 & 9.4 & 9.4 & 96.0 \\
Ngunut & 2 & 1.3 & 1.3 & 97.3 \\
Pojong & 4 & 2.7 & 2.7 & 100.0 \\
\hline
\end{tabular}

Sumber: data penelitian 
Berdasarkan Tabel 1 dapat diketahui bahwa jumlah responden terbanyak yang dijadikan sampel bertempat tinggal di Kecamatan Playen. Kecamatan Playen saat ini juga menjadi Pusat pembinaan keterampilan kewirausahaan dari para Tenaga Kerja Wanita purna di kabupaten Gunung Kidul. Dari obyek penelitian terpilih pada 9 Kecamatan tersebut, kemudian dibagikan kuesioner kepada seluruh Responden. Kuesioner yang dibagikan berjumlah 210, dan yang kembali berjumlah 149, namun dari sejumlah kuesioner yang kembali hanya 135 kuesioner yang memenuhi syarat untuk dianalisis, sedangkan sisanya tidak bisa dianalisis lebih lanjut karena pengisian kuesioner tidak lengkap atau dalam satu pertanyaan ada dua jawaban. Berdasar isian kuesioner dari responden, dapat digambarkan beberapa karakteristik responden sebagai berikut.

\section{Karakteristik Responden berdasar Jenis Kelamin}

Seluruh responden yang menjadi obyek penelitian ini adalah perempuan (100\%). Berdasarkan data yang diperoleh dari Dinas Sosial Tenaga Kerja dan Transmigrasi (Dinsoskertrans) Kabupaten Gunung Kidul, jumlah total mantan TKW informal adalah 400 orang. Yang dimaksud dengan TKW informal adalah mereka yang bekerja di luar negeri di sektor informal (Pembantu Rumah Tangga), sedangkan yang dijadikan sampel dalam penelitian ini adalah 135 orang. Mengapa keseluruhan mantan Tenaga Kerja Indonesia yang bekerja di luar negeri sebagai pembantu rumah tangga adalah wanita, karena permintaan dari luar negeri untuk lowongan tersebut adalah untuk wanita, sedangkan Tenaga Kerja Indonesia yang berjenis kelamin laki-laki, banyak menempati pekerjaan di sektor formal, seperti pabrik, perkebunan dan lain-lain.

\section{Karakteristik Responden berdasar Umur}

Apabila dianalisis berdasar umurnya, nampak bahwa sebagian besar responden yakni sebanyak 27 orang $(20 \%)$ berusia di antara 17-40 tahun dan 108 orang (80\%) yang berumur antara 41-59 tahun. Hal ini menunjukkan bahwa sebagian besar TKW yang di Gunung Kidul berusia diatas 40 tahun. Berikut adalah tabel 2 yang menunjukkan usia responden:

Tabel 2

Karakteristik Responden berdasar Umur

\begin{tabular}{cccc}
\hline \hline No. & Umur & Jumlah & \% \\
\hline 1 & $17-40$ & 27 & 20 \\
2 & $41-59$ & 108 & 30 \\
\hline \multicolumn{2}{r}{ Total } & 135 & 100 \\
\hline
\end{tabular}

Sumber: data penelitian

\section{Karakteristik Responden berdasar Tingkat Pendidikan}

Hasil penelitian yang dilakukan Lestari dan Wijaya, (2012) menyimpulkan bahwa tingkat pendidikan mempengaruhi Intensi Kewirausahaan. Adapun berdasarkan hasil analisis data penelitian, dapat diketahui terdapat sebanyak 13 orang (9\%) TKW yang memiliki tingkat pendidikan Sekolah Lanjutan Tingkat Atas (SLTA), sedangkan jumlah terbanyak adalah lulusan Sekolah Lanjutan Tingkat Pertama (SLTP) yaitu sebanyak 108 orang $(80 \%)$, sedang sisanya sebanyak 14 orang $(11 \%)$ berpendidikan Sekolah Dasar (SD). Secara lebih jelas dapat dilihat pada Tabel 3 berikut:

Tabel 3

Karakteristik Responden berdasar Tingkat Pendidikan

\begin{tabular}{cccc}
\hline \hline No. & $\begin{array}{c}\text { Tingkat } \\
\text { Pendidikan }\end{array}$ & Jumlah & \% \\
\hline 1 & SLTA & 13 & 9 \\
2 & SLTP & 108 & 80 \\
3 & SD & 14 & 11 \\
\hline & Total & 135 & 100 \\
\hline
\end{tabular}

Sumber: data penelitian

\section{Analisis Motif Menjadi TKW di Luar Negeri}

Hasil analisis data penelitian pada tabel 4, dapat diketahui terdapat sebanyak 70 orang $(42,9 \%)$ TKW bekerja di luar negeri 
karena alasan ekonomi (gaji yang lebih besar dibanding bekerja di dalam negeri) dan sebanyak $39(28,8 \%)$ orang memilih bekerja di luar negeri karena terbatasnya lapangan kerja yang tersedia bagi mereka. Selanjutnya sebanyak 26 orang $(19,3 \%)$ memilih bekerja di luar negeri karena kemudahan ijin. Secara lebih jelas dapat dilihat pada Tabel 4 berikut:

\section{Tabel 4}

\section{Alasan Memilih Bekerja di Luar Negeri}

\begin{tabular}{clcc}
\hline No. & $\begin{array}{c}\text { Alasan Bekerja di } \\
\text { LN }\end{array}$ & Jumlah & \% \\
\hline 1 & Gaji besar & 70 & 42,9 \\
2 & Sulit cari kerja di GK & 39 & 28,2 \\
3 & Mudah ijinnya & 26 & 19,3 \\
\hline & Total & 135 & 100 \\
\hline
\end{tabular}

Sumber: data penelitian

\section{Karakteristik Responden berdasar Pengalaman Berwirausaha}

Pengalaman menjadi pelajaran yang baik bagi seseorang, karena dengan pe ngalaman seseorang tahu mana yang benar dan mana yang salah. Karena dari pengalaman akan muncul kreativitas dan inovasi untuk melakukan kegiatan usaha.

Tabel 5

Karakteristik Responden berdasar Pengalaman Berwirausaha

\begin{tabular}{|c|c|c|c|}
\hline No. & Keterangan & Jumlah & \%\% \\
\hline 1 & Punya Pengalaman & 40 & 30 \\
\hline 2 & $\begin{array}{l}\text { Tidak punya } \\
\text { Pengalaman }\end{array}$ & 95 & 70 \\
\hline & Total & 135 & 100 \\
\hline
\end{tabular}

Sumber: data penelitian

Berdasarkan hasil penelitian seperti yang tercantum di tabel 5, diketahui bahwa dari 135 jumlah TKW yang menjadi responden, sebanyak 95 orang (70\%) tidak mempunyai pengalaman berwirausaha sedang sisanya 40 orang $(30 \%)$ mempunyai pengalaman wirausaha.

Bagaimana para mantan TKW mendapat pengalaman berwirausaha ini ada beberapa cara, ada yang dengan membantu tetangga yang berwirausaha, ada yang melalui praktek di lingkungan keluarga, atau ada yang mencoba sendiri berwirausaha. Dengan pangalaman wirausaha ini, para mantan TKW dapat mengetahui bagaimana menjalankan usaha. Pada umumnya manusia akan memilih berwirausaha pada bidang yang menjadi pengalamannya atau bidang yang ada hubungannya dengan pengalaman berwirausaha yang pernah dilakukannya (Kolvereid, 1996).

\section{Hasil Uji Validitas Variabel Kepribadian}

Berdasarkan perhitungan dengan product moment pearson menunjukkan adanya signifikansi korelasi antara masing-masing indikator dengan variabel dengan besaran totalnya diatas 0,7 sedangkan hasil uji validitas butir pernyataan 1 sampai dengan 5 dikatakan valid karena memiliki faktor loading $>0,4$. Dari hasil tersebut disimpulkan bahwa pernyataan 1 sampai dengan 5 benar-benar sebagai indikator kepribadian.

\section{Hasil Uji Validitas Variabel Lingkungan}

Berdasarkan perhitungan dengan menggunakan analisis faktor menunjukkan nilai total faktor loading untuk kelima pertanyaan lingkungan lebih dari 0,4. Dengan demikian butir pernyataan 1 sampai dengan 5 dikatakan valid karena memiliki faktor loading >0,4. Dari hasil tersebut disimpulkan bahwa pernyataan 1 sampai dengan 5 benar-benar sebagai indikator lingkungan.

\section{Hasil Uji Validitas Variabel Intensi}

Berdasarkan perhitungan dengan analisis faktor terlihat adanya signifikansi korelasi antara masing-masing komponen dengan besaran totalnya. Butir pernyataan 1 sampai dengan 5 dikatakan valid karena memiliki faktor loading $>0,4$.

Dari hasil tersebut disimpulkan bahwa pertanyaan 1 sampai dengan 5 benar-benar sebagai indikator intensi. Dari hasil uji validitas masing-masing indikator terhadap variabel, dapat disimpulkan bahwa kuesioner yang diberikan kepada responden, dinyatakan layak. 


\section{Hasil Uji Reliabilitas}

Uji reliabilitas dilakukan dengan menggunakan program SPSS dengan mencari nilai koefisien reliabilitas (alpha). Apabila Cronbach alpha $>0,6$ dan nilainya positif, berarti variabel yang diukur bersifat reliabel. Hasil perhitungan dengan menggunakan program SPSS menunjukkan nilai alpha 0,8435 . Nilai ini lebih besar dari 0,6 sehingga dapat dinyatakan bahwa variabel yang diukur bersifat reliabel.

\section{Hasil Uji Normalitas}

Uji normalitas dilakukan untuk melihat apakah ada dalam model regresi variabel endogen dan variabel eksogen keduanya mempunyai distribusi normal atau tidak. Model regresi yang baik adalah model regresi yang berdasarkan distribusi normal. Output histogram menunjukkan pola distribusi mendekati normal dan grafik normal yang menunjukkan penyebaran titik-titik di sekitar garis diagonal dan mengikuti arah garis diagonal. Hal ini mengindikasikan model regresi memenuhi asumsi normalitas. Berikut gambar 2 adalah hasil uji normalitas.

\section{Normal P-P Plot of Regression S}

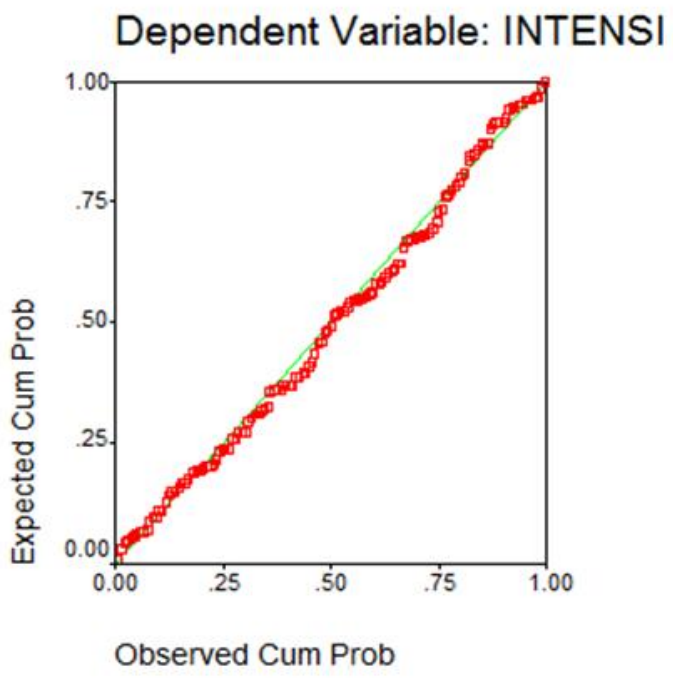

Sumber: data penelitian

Gambar 2 Hasil Uji Normalitas

\section{Hasil Uji Multikolinearitas}

Berdasarkan hasil analisis data penelitian, setelah dilakukan uji multikolinearitas, menunjukkan hasil nilai angka tolerance mendekati angka 1 dan mempunyai nilai VIF (Variance Inflation Factor) disekitar angka 1. Hal ini menunjukkan bahwa tidak terdapat multikolinearitas pada data yang diperoleh. Berikut adalah hasil uji multikolinieritas.

Tabel 6

Hasil Uji Multikolinieritas

\begin{tabular}{lcc}
\hline \hline \multicolumn{1}{c}{ Model } & $\begin{array}{c}\text { Collinearity } \\
\text { Statistics } \\
\text { Tolerance }\end{array}$ & VIF \\
\hline (Constant) & & \\
Kepribadian & .695 & 1.438 \\
Lingkungan & .867 & 1.154 \\
Demografi & .665 & 1.504 \\
Sumber: data penelitian & &
\end{tabular}

\section{Hasil Uji Heteroskedastisitas}

Hasil uji heteroskedastisitas diketahui bahwa tidak ada pola yang jelas, serta titiktitik yang menyebar diatas dan dibawah angka nol pada sumbu $Y$, maka dapat di simpulkan bahwa tidak terjadi heteroskedastisitas. Berikut adalah hasil uji Heteroskedastisitas.

Berdasarkan tabel 7 diketahui bahwa seluruh variabel bebas memiliki nilai probabilitas yang lebih besar dari taraf signifikan 0,05. Hal ini berarti bahwa dalam model regresi tersebut tidak terjadi heterokedastisitas.

\section{Hasil Regresi Berganda}

Model persamaan regresi berganda menggambarkan hubungan linier antara dua atau lebih variabel bebas terhadap satu variabel terikat. Dalam penelitian ini analisis regresi berganda digunakan untuk mengetahui pengaruh variabel kepribadian, lingkungan, dan demografi terhadap Intensi kewirausahaan.

Proses penghitungan regresi dilakukan dengan bantuan SPSS versi 15.0. Hasil perhitungan statistik dengan program SPSS 
Tabel 7

Hasil Uji Heteroskedastisitas

\begin{tabular}{|c|c|c|c|c|}
\hline $\begin{array}{c}\text { Variabel } \\
X\end{array}$ & Sig & $\mathbf{a}$ & Keterangan & Kesimpulan \\
\hline Kepri & 0,776 & 0,05 & Tidak signifikan & Tdk ada heteroskedastisitas \\
\hline Lingku & 0,752 & 0,05 & Tidak signifikan & Tdk ada heteroskedastisitas \\
\hline Demog & 0.831 & 0,05 & Tidak signifikan & Tdk ada heteroskedastisitas \\
\hline
\end{tabular}

Sumber: data penelitian

diketahui bahwa regresi linier berganda, menghasilkan nilai $R$ sebesar 0,483 . Hasil ini menunjukkan adanya korelasi ganda (kepribadian, lingkungan dan demografi) dengan intensi kewirausahaan.

Sementara itu nilai Adjusted R Square sebesar 0,233 menujukkan besarnya peran atau kontribusi variabel kepribadian, lingkungan dan demografi hanya 23,3\%, sisanya sebesar $73,7 \%$ dipengaruhi variabel lain diluar penelitian ini. Dari output SPSS menunjukkan bahwa persamaan regresi berganda adalah:

In Kew $=1,148+0,146$ Kep $+0,338$ Ling + 0,247 Dem

In Kew: Intensi kewirausahan

Kep : Kepribadian

Ling : Lingkungan

Dem : Demografi

Konstanta sebesar $+1,148$ menunjukkan bahwa jika tidak ada variabel kepribadian, lingkungan dan demografi, maka besarnya intensi kewirausahaan sebesar 1,148. Koefisien regresi Kepribadian (Kep) sebesar $+0,146$ menunjukkan arah hubungan antara kepribadian dengan intensi sama, dalam arti apabila ada perubahan kepribadian akan menyebabkan perubahan intensi kewirausahaan, demikian sebaliknya. Besaran angka 0,146 berarti bahwa setiap perubahan kepribadian 1 satuan akan meningkatkan intensi kewirausahaan sebesar 0,146 satuan.

Koefisien regresi Lingkungan (Ling) sebesar +0,338 menunjukkan arah hubungan antara lingkungan dengan minat dan bakat sama, dalam arti apabila ada peningkatan lingkungan akan menyebabkan peningkatan intensi kewirausahaan, demikian sebalik- nya. Besaran angka 0,338 berarti bahwa setiap peningkatan lingkungan 1 satuan akan meningkatkan intensi kewirausahaan sebesar 0,388 satuan. Koefisien regresi Demografi (Dem) sebesar +0,247 menunjukkan arah hubungan antara variabel demografi dengan intensi sama, dalam arti apabila ada peningkatan demografi akan menyebabkan peningkatan intensi kewirausahaan, demikian sebaliknya. Besaran angka 0,247 berarti bahwa setiap peningkatan demografi 1 satuan akan meningkatkan intensi kewirausahaan sebesar 0,247 satuan.

\section{Korelasi Parsial}

Koefisien korelasi parsial digunakan untuk mengetahui keeratan hubungan antara variabel bebas secara individu, yakni Kepribadian, Lingkungan, dan Demografi terhadap variabel terikat.

\section{Analisis Hubungan Antar Variabel Pengaruh Kepribadian (Kep)}

Besar hubungan antara variabel kepribadian (Kep) dengan intensi kewirausahaan dihitung dengan koefisien korelasi sebesar 0,354. Berdasarkan nilai koefisien korelasi tersebut diketahui bahwa pengaruh kepribadian terhadap intensi para TKW purna dalam berwirausaha cukup kuat dan positif.

Berarti bahwa kenaikan kepribadian akan menyebabkan kenaikan pada intensi kewirausahaan para TKW purna di Gunung Kidul. Demikian sebaliknya, berkurangnya faktor kepribadian yang dinyatakan dalam butir-butir pertanyaan atau pernyataan akan menyebabkan menurunnya intensi kewirausahaan. 


\section{Pengaruh Lingkungan (Ling)}

Besar hubungan antara variabel lingkungan (Ling) dengan intensi kewirausahaan dihitung dengan koefisien korelasi sebesar 0,449 . Berdasarkan nilai koefisien korelasi tersebut diketahui bahwa pengaruh Lingkungan terhadap intensi TKW purna di Gunung Kidul dalam berwirausaha cukup kuat dan positif. Berarti bahwa kenaikan faktor lingkungan akan menyebabkan kenaikan pada intensi kewirausahaan para TKW purna di Gunung Kidul. Sebaliknya, berkurangnya faktor lingkungan yang dinyatakan dalam butir-butir pertanyaan atau pernyataan akan menyebabkan menurunnya intensi kewirausahaan.

Tabel 9

Hasil Uji Korelasi

\begin{tabular}{lcccc}
\hline \hline \multicolumn{1}{c}{ Keterangan } & Intensi & Kepribadian & Lingkungan & Demografi \\
\hline PearsonCorrel & & & & \\
Intensi & .000 & .354 & .449 & .234 \\
Kepribadian & .354 & .000 & 593 & .114 \\
Lingkungan & .459 & .593 & .000 & .224 \\
Demografi.234 & .113 & .224 & .000 & \\
\hline Sig.(1-tailed) & & & & \\
Intensi & - & .000 & .000 & .003 \\
Kepribadian & .000 & - & .000 & .096 \\
Lingkungan & .000 & .000 & - & .005 \\
Demografi & .003 & .096 & .005 & - \\
\hline N Intensi & & & & \\
Intensi & 135 & 135 & 135 & 135 \\
Kepribadian & 135 & 135 & 135 & 135 \\
Lingkungan & 135 & 135 & 135 & 135 \\
Demografi & 135 & 135 & 135 & 135 \\
\hline S & & & &
\end{tabular}

Sumber: Hasil Penelitian

\section{Pengaruh Demografi (Dem)}

Besar hubungan antara variabel demografi (Dem) dengan intensi kewirausahaan ditunjukkan dengan nilai koefisien korelasi sebesar 0,234. Berdasarkan nilai koefisien korelasi tersebut diketahui bahwa pengaruh demografi terhadap intensi kewirausahaan para TKW purna dalam berwirausaha positif namun relatif lemah. Berarti bahwa kenaikan demografi akan menyebabkan kenaikan pada intensi kewirausahaan para TKW purna. Apabila faktor-faktor demografi yang dinyatakan dalam butir-butir pertanyaan atau pernyataan tersebut berbeda maka akan menyebabkan menurunnya intensi kewirausahaan. Secara teoritis hubungan lingkungan dengan intensi lebih kuat dibandingkan hubungan antara kepribadian dengan intensi maupun hubungan antara demografi dengan intensi yang ditunjukkan dengan nilai koefisien korelasi sebesar 0,449 . Tingkat signifikansi koefisien korelasi menghasilkan angka 0,000. Karena probabilitas jauh di bawah 0,05 maka korelasi antar variabel sangat nyata (signifikan).

\section{Pengujian Hipotesis}

Pengujian hipotesis dimaksudkan untuk membuktikan apakah terdapat pengaruh yang signifikan dari variabel eksogen terhadap variabel endogen. Untuk menguji apakah masing-masing variabel kepribadian, lingkungan dan demografi berpengaruh terhadap intensi dilakukan dengan uji t.

\section{Variabel Kepribadian}

Nilai probabilitas t-hitung variabel kepribadian sebesar 0,044<0,05 menunjukkan 
bahwa $\mathrm{H}_{1}$ yang menyatakan bahwa kepribadian berpengaruh terhadap intensi kewirausahaan diterima. Menurut Ozaralli (2016), wirausahawan adalah orang yang memiliki kepribadian yang kuat dari dalam dirinya untuk memperoleh suatu tujuan, suka menguji coba atau bereksperimen untuk menampilkan kebebasan dirinya di luar kekuasaan orang lain. Selain itu, Suharti dan Sirine (2011), juga menemukan bahwa salah satu faktor yang mempengaruhi intensi kewirausahaan adalah kepribadian. Dari hasil analisis data diketahui bahwa kepribadian para TKW purna di Gunung Kidul berpengaruh terhadap intensi berwirausaha. Menurut Sinha (1996), kepribadian yang tegas, ulet dan pantang menyerah merupakan faktor kuat dalam membentuk jiwa wirausaha yang efektif. Berdasarkan hasil penelitian yang dilakukan oleh nya disimpulkan bahwa, terdapat tujuh hal penting dalam mengatasi hambatan kewirausahaan, salah satunya yaitu karakter kepribadian yang kuat.

\section{Variabel Lingkungan}

Nilai probabilitas $\mathrm{t}$-hitung variabel lingkungan sebesar 0,001 $<0,05$ menunjukkan bahwa $\mathrm{H}_{2}$ yang menyatakan bahwa lingkungan berpengaruh terhadap intensi kewirausahaan diterima. Dukungan keluarga terhadap para TKW purna yang berencana menjadi wirausaha, baik berupa dukungan moril maupun materiil (modal) dapat menambah keyakinan para TKW purna dalam memulai usaha. Menurut Qureshi et al. (2016), lingkungan keluarga dan intervensinya memiliki pengaruh yang kuat terhadap minat berwirausaha dari individu. Dengan demikian, para TKW purna yang mempunyai anggota keluarga atau tetangga yang berwirausaha dan mendukung untuk memulai usaha akan mempunyai intensi kewirausahaan yang lebih besar dan lebih siap untuk berwirausaha. Faktor lain yang mendorong TKW purna untuk berwirausaha juga berasal dari tuntutan kebutuhan ekonomi keluarga, mereka ingin mencari sumber pendapatan untuk keluarga.

Sarwono (2011), secara empiris, intensi wirausaha individu banyak dipengaruhi oleh tuntutan akan pemenuhan kebutuhan ekonomi. Berdasarkan data yang diperoleh, dapat diketahui bahwa sebanyak 55,7\% tujuan TKW bekerja di luar negeri adalah untuk membantu suami mereka dalam memenuhi kebutuhan ekonomi keluarga.

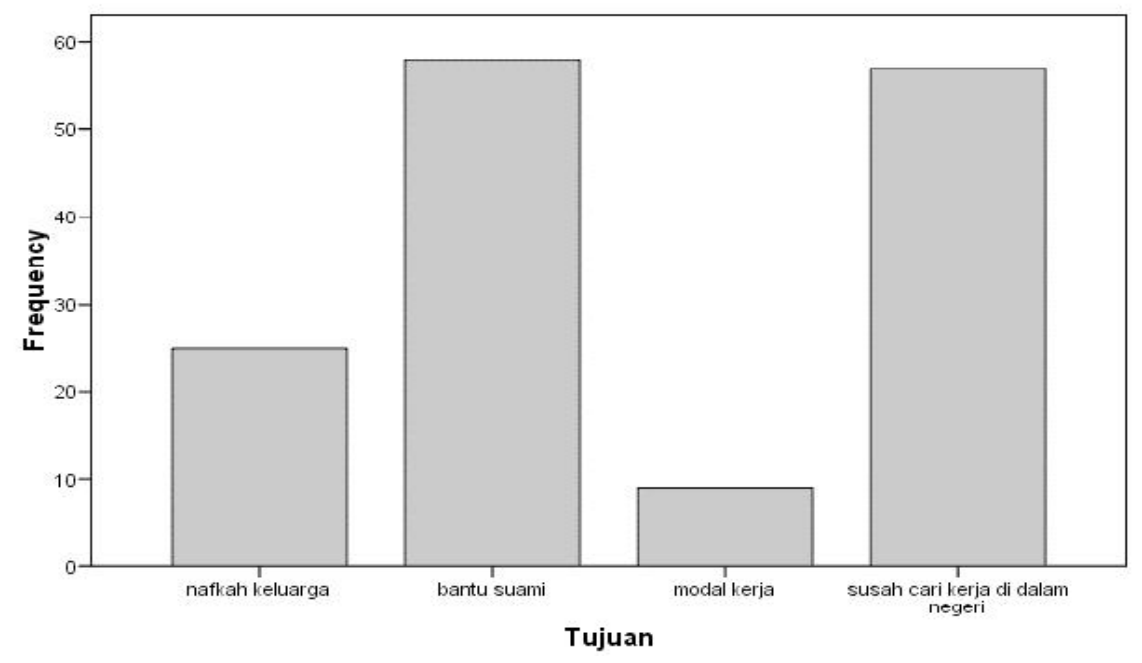

Gambar 3 
Dan sebesar 51,7\% mereka terpaksa ke luar negeri karena kurangnya ketersediaan lapangan kerja di Gunung Kidul. Grafik yang menunjukkan tujuan bekerja di luar negeri adalah pada gambar 3 .

Berdasarkan gambar 3, diketahui apabila tersedia lapangan kerja yang cukup, maka minat untuk bekerja di luar negeri menjadi berkurang. Dalam hal ini pemerintah Kabupaten Gunung Kidul, diharapkan ikut membantu turun tangan. Salah satu kebijakan yang dapat dilakukan untuk membuka lapangan kerja, yaitu dengan membuka peluang usaha. Peluang usaha yang dimaksud salah satunya dengan mendorong masyarakat Gunung Kidul, khususnya para TKW purna untuk berwirausaha. Dengan memberikan bimbingan dan pelatihan yang tepat pada mereka yang memiliki intensi beriwausaha, dalam beberapa tahun ke depan, para TKW purna Gunung Kidul diharapkan akan memiliki kemandirian ekonomi.

\section{Variabel Demografi}

Nilai probabilitas t-hitung variabel demografi sebesar 0,070 >0,05 menunjukkan bahwa $\mathrm{H}_{3}$ yang menyatakan bahwa demografi berpengaruh terhadap intensi kewirausahaan ditolak. Faktor demografi meliputi jenis kelamin, umur, pendidikan, pelatihan dan pengalaman berwirausaha ternyata tidak mempengaruhi TKW purna dalam berwirausaha. Hal ini bisa terjadi dikarenakan motif ekonomi dan keinginan yang kuat mereka untuk merantau di luar negeri, untuk bisa mencapai kemandirian ekonomi. Selain itu, faktor mental dan karakter yang berani mengambil resiko (didasarkan atas keberanian mereka yang nekat merantau di luar negeri) membuat secara demografi, para TKW purna tidak surut intensinya pada kewirausahaan. Artinya, meskipun mereka berjenis kelamin perempuan, tidak memiliki pendidikan yang tinggi serta kurangnya pengalaman dalam hal berwirausaha, tidak mempengaruhi minat mereka untuk berwirausaha. Hasil ini berbeda dengan hasil penelitian Cheraghi dan Schott, (2015) yang menyatakan bahwa pendidikan dan pelatihan kewirausahaan, baik selama dan setelah sekolah formal, sangat bermanfaat dalam mengembangkan kompetensi dan selama fase karir yaitu, berniat untuk memulai bisnis, memulai bisnis, dan menjalankan bisnis.

\section{Pembahasan}

Perkembangan terakhir menunjukkan bahwa Kabupaten Gunung Kidul mulai mengembangkan kewirausahaan sebagai upaya memberdayakan masyarakat miskin, upaya yang dimaksud antara lain pembangunan infrastruktur yang bertujuan memudahkan akses jalan menuju lokasi yang sulit. Selain pembangunan jalan, jembatan dan infrastruktur lainnya, pemerintah daerah Gunung Kidul juga banyak membuka akses jalan untuk peningkatan kunjungan wisata daerah. Karena dengan terbukanya akses ini, maka akan semakin banyak wisatawan yang datang ke Gunung Kidul, semakin banyak wisatawan yang datang, itu berarti akan membawa dampak yang positif untuk terbukanya peluang industri wisata lokal. Peluang industri ini, berbareng dengan pelatihan keterampilan dan manajemen sederhana bagi masyarakat, khususnya masyarakat miskin yang memiliki intensi kewirausahaan, maka diharapkan dapat membantu program pengentasan kemiskinan di wilayah ini.

Beberapa waktu terakhir pemerintah daerah Gunung Kidul bekerjasama dengan para akademisi baik PTN maupun PTS membekali para mantan Tenaga Kerja Wanita (TKW) dengan kemampuan wirausaha melalui penelitian dan pelatihan. Diantaranya dengan memberikan pelatihan khusus kewirausahaan baik berupa materi yang diberikan secara klasikal maupun dengan praktek. Selain itu pembentukan paguyuban dan koperasi yang dikelola oleh para mantan TKW dilakukan sebagai wahana pelatihan sekaligus praktek wirausaha. Terdapat beberapa koperasi di beberapa 
Kecamatan, yang hampir semuanya mempunyai unit bisnis yang dikelola oleh para mantan TKW di wilayah Gunung Kidul.

Selama ini masyakarat meyakini, bahwa memulai usaha tidak akan bisa tanpa modal yang memadai, niat dan dukungan saja tidak akan cukup, oleh karenanya, dalam konsep memandirikan ekonomi rakyat, perlu kerjasama dan saling memahami, antara berbagai kalangan masyarakat. Khususnya pada kasus mencapai kemandirian ekonomi bagi para TKW purna ini. Setelah mengetahui tingkat keinginan mereka untuk berwira usaha, dan juga mengetahui faktor yang dominan mempengaruhi intensi berwirausaha, langkah selanjutnya adalah, mengupayakan berbagai hal guna mewujudkan harapan tersebut. Pemerintah, khususnya pemerintah Kabupaten Gunung Kidul, harus berpikir keras untuk memecahkan persoalan ini.

Fenomena yang terjadi selama ini, banyak pelaku usaha yang mengeluhkan mengenai sulitnya akses terhadap modal, aliran modal terhambat oleh skema kredit yang mensyaratkan agunan, dan keteraturan administrasi usaha (Indrijatiningrum, 2005). Hal ini artinya pihak perbankan hanya bersedia memberikan pinjaman modal jika pelaku usaha memiliki agunan dan usaha sudah berjalan beberapa waktu, sedangkan kondisi para TKW purna, belum memiliki usaha dan juga tidak memiliki agunan. Menurut Ozaralli dan Rivenburgh, (2016) terdapat beberapa faktor yang harus dilakukan untuk membangun kemandirian ekonomi, melalui kewirausahaan diantaranya adalah, membentuk lingkungan usaha, memberikan pelatihan usaha dan bantuan permodalan. Pertanyaannya adalah bagaimana pemerintah Kabupaten Gunung Kidul dapat membantu permodalan pada mereka untuk berwirausaha agar dapat mencapai kemandirian ekonomi? Berapa banyak dana APBD yang harus disalurkan untuk membantu permodalan mereka? Mengingat Kabupaten Gunung Kidul merupakan Kabupaten yang menempati urutan kedua dalam kemiskinan dibanding dengan Kabupaten lainnya di Daerah Istimewa Yogyakarta, maka memberikan modal dengan mengandalkan APBD saja tidaklah cukup. Untuk itu perlu upaya strategi perolehan bantuan permodalan dari sektor lain, yang bisa mengatasi persoalan kemiskinan ini. Salah satu alternatif permodalan bagi masyarakat Muslim di Indonesia adalah optimalisasi pemanfaatan dana wakaf tunai.

Wacana pemanfaatan penggunaan dana wakaf tunai untuk kepentingan pengentasan kemiskinan perlu dilakukan, karena, potensi dana wakaf tunai di Indonesia, ini cukup besar, dan belum dioptimalkan penggunaannya. Selama ini, masyarakat hanya mengenal adanya wakaf yang berupa tanah dan bangunan saja. Padahal di Indonesia, dan khususnya Gunung Kidul, terdapat potensi adanya wakaf tunai yang bisa dimanfaatkan. Pengelolaan wakaf tunai untuk kemandirian ekonomi, di Indonesia, selama ini sebenarnya sudah dilakukan, namun implementasinya masih sangat terbatas (Mughnisani, 2015). Menurut Gamal, (2007) selama ini masyarakat Indonesia pada umumnya lebih familiar dengan zakat, infaq dan shadaqoh sebagai sarana berbagi harta dengan orang miskin. Padahal wakaf tunai merupakan salah satu cara yang juga dapat dilakukan untuk menggalang pendanaan demi kemandirian ekonomi masyarakat miskin. Hal ini membuktikan bahwa bukan hal yang tidak mungkin untuk mewujudkan kemandirian ekonomi masyarakat, khususnya para mantan TKW. Hingga saat ini pemerintah Provinsi DIY dan pemerintah daerah Gunung Kidul khususnya, hanya konsentrasi pada pendataan jumlah penduduk miskin saja. Berikut adalah data yang menunjukkan tingkat kemiskinan Kabupaten di Yogyakarta (Tabel 10).

Berdasarkan Tabel 10, dapat dilihat bahwa Gunung Kidul merupakan daerah termiskin di DIY. Berdasarkan data yang digali dari obyek penelitian diketahui bahwa Gunung Kidul memiliki jumlah penduduk miskin sebesar $22,72 \%$ dari total penduduk 
DIY. Angka tersebut berarti bahwa Gunung Kidul adalah Kabupaten dengan kemiskinan nomor 2 dibanding Kabupaten lainnnya. Situasi tersebut dikarenakan kondisi geografis Gunung Kidul yang terletak di pesisir pantai selatan dan kondisi tanah kapurnya, sehingga menjadikan tanah di Gunung kidul kurang subur. Kondisi geografis yang kurang menguntungkan dibanding dengan Kabupaten lainnya, mengakibatkan Gunung Kidul menjadi daerah dengan angka ke- miskinan yang tinggi, oleh karenanya, menjadi hal yang tidak mungkin bagi pemerintah daerah untuk dapat memberikan bantuan modal kepada mereka semua, sehingga perlu dicari alternatif sumber permodalan bagi mereka.

Salah satu alternatif permodalan yang bisa digunakan dalam mengatasi kemiskinan di Gunung Kidul, yaitu dengan mengoptimalkan pemanfaatan wakaf tunai.

Tabel 10

Jumlah Penduduk Miskin dan Garis Kemiskinan menurut Kabupaten/Kota di D.I. Yogyakarta 2011 - 2012

\begin{tabular}{|c|c|c|c|c|c|c|}
\hline \multirow{3}{*}{ Kabupaten/Kota } & \multicolumn{3}{|c|}{ September 2011} & \multicolumn{3}{|c|}{ September 2012} \\
\hline & \multirow{2}{*}{$\begin{array}{c}\text { Garis Kemiskinan } \\
\text { (Rp/kap/bulan) }\end{array}$} & \multicolumn{2}{|c|}{ Penduduk Miskin } & \multirow{2}{*}{$\begin{array}{c}\text { Garis Kemiskinan } \\
\text { (Rp/kap/bulan) }\end{array}$} & \multicolumn{2}{|c|}{ Penduduk Miskir } \\
\hline & & $\begin{array}{c}\text { Jumlah } \\
(000)\end{array}$ & $\%$ & & $\begin{array}{c}\text { Jumlah } \\
(000)\end{array}$ & $\%$ \\
\hline 1. Kulonprogo & 240.301 & 92,8 & 23,62 & 256.575 & 92,4 & 23,32 \\
\hline 2. Bantul & 264.546 & 159,4 & 17,28 & 284.923 & 158,8 & 16,97 \\
\hline 3. Gunungkidul & 220.479 & 157,1 & 23,03 & 238.438 & 156,5 & 22,72 \\
\hline 4. Sleman & 267.107 & 117,3 & 10,61 & 288.048 & 116,8 & 10,44 \\
\hline 5. Yogyakarta & 314.311 & 37,7 & 9,62 & 340.324 & 37,6 & 9,38 \\
\hline DIY & 257.909 & 564,3 & 16,14 & 270.110 & 562,1 & 15,88 \\
\hline
\end{tabular}

Sumber : Susenas, Badan Pusat Statistik Provinsi D.I. Yogyakarta diolah

Adapun daerah atau Kecamatan dengan angka kemiskinan tertinggi di Gunung Kidul adalah Wonosari (kota Kabupaten), Playen, Semin, Ngawen, Patuk, Saptosari, Pojong dan Nglipar. Kemiskinan yang melanda 7 Kecamatan ini, berdampak pada rendahnya tingkat kesehatan dan juga pendidikan penduduknya, sehingga, banyak penduduk dengan usia kerja yang menganggur, karena tidak mampu bersaing dengan penduduk di wilayah lain yang lebih baik. Hal ini mendorong mereka untuk nekat bekerja sebagai tenaga kerja (buruh rumah tangga) ke luar negeri. Berdasarkan data yang diperoleh 55,7\% motif utama bekerja sebagai buruh di luar negeri adalah desakan ekonomi. Desakan ekonomi yang dimaksud adalah, untuk memenuhi kebutuhan keluarga (membantu suami mencari nafkah keluarga) dan sebesar 51,7\% TKW memilih bekerja di luar negeri karena kurangnya ketersediaan lapangan pekerjaan yang sesuai. Dilihat dari data yang berhasil diperoleh, $100 \%$ penduduk yang menjadi TKI informal (buruh rumah tangga) dari Gunung Kidul adalah wanita. Alasannya, karena lowongan yang dibuka untuk pekerjaan buruh rumah tangga adalah wanita.

Gunung Kidul memang tercatat sebagai daerah miskin di DIY, akan tetapi bukan berarti tidak ada potensi kekayaan yang ada. Terbukti beberapa tahun terakhir, banyak investor yang menginvestasikan dananya untuk pengembangan wisata di Gunung 
Kidul. Adanya potensi kekayaan di Gunung Kidul, mengindikasikan adanya potensi penduduk yang menyisihkan dananya untuk urusan keagamaan. Salah satu bagian dari urusan keagamaan adalah wakaf, karena seperti Kabupaten lainnya di DIY, penduduk di Gunung Kidul mayoritas beragama Islam. Berdasarkan data yang diperoleh dari Departemen Agama (Depag) Gunung Kidul, selama ini, angka wakaf menunjukkan kenaikan. Berikut adalah jumlah wakaf di Kabupaten Gunung Kidul terkini (Tabel 11).

Tabel 11

Jumlah Wakaf di Kabupaten Gunung Kidul Tahun 2015

\begin{tabular}{clccc}
\hline \hline NO & Kecamatan & Jumlah Satuan & Luas (Ha) & \% \\
\hline 1 & Wonosari & 226 & 9,46 & 14,36 \\
2 & Playen & 187 & 12,28 & 11,89 \\
3 & Paliyan & 90 & 3,67 & 5,73 \\
4 & Panggang & 56 & 2,96 & 3,56 \\
5 & Semanu & 106 & 3,49 & 6,74 \\
6 & Tepus & 46 & 1,84 & 2,92 \\
7 & Rongkop & 77 & 2,4 & 4,90 \\
8 & Karangmojo & 123 & 6,1 & 7,82 \\
9 & Pojong & 103 & 4,57 & 6,55 \\
10 & Ngawen & 120 & 4,40 & 7,63 \\
11 & Semin & 135 & 4,68 & 8,58 \\
12 & Nglipar & 87 & 3,48 & 5,53 \\
13 & Patuk & 65 & 2,23 & 4,13 \\
14 & Saptosari & 136 & 1,54 & 2,28 \\
15 & Gendangsari & 142 & 1,53 & 2,67 \\
16 & Girisubo & 29 & 0,85 & 1,84 \\
17 & Tanjungsari & 30 & 0,88 & 1,90 \\
18 & Purwosari & 15 & 0,46 & 0,95 \\
\hline & Total & 1,573 & 66,81 & 100 \\
\hline
\end{tabular}

Sumber : Dept. Agama GK diolah

Berdasarkan tabel 11 tersebut, dapat diketahui bahwa wakaf yang ada di Gunung Kidul masih berupa wakaf benda tak bergerak (tanah). Berdasarkan data tersebut di atas, diketahui bahwa jumlah total wakaf tanah di Kabupaten Gunung Kidul ada 66,81 ha, dari jumlah tersebut terdapat 9,15\% yang belum tersertifikasi (masih belum ada sertifikatnya). Tanah wakaf yang belum memiliki sertifkat inilah yang seringkali menimbulkan pemasalahan. Menurut Utami dan Munawar (2014), beberapa kasus yang terjadi sebagai dampak dari tanah wakaf yang belum bersertifikat, diantaranya ada- lah, sulit untuk mendapatkan ijin mendirikan bangunan karena tidak lengkapnya syarat administrasi (serifikat), adanya tuntutan dari salah satu ahli waris yang tidak merelakan tanah tersebut diwakafkan, sehingga menimbulkan konflik yang berdampak hukum. Kendala utama dari tidak adanya sertifikat, karena wakif yang tidak berkenan untuk mengeluarkan dana tambahan untuk pengurusan sertifikat. Hal ini tentu harus dipikirkan solusinya agar tidak menimbulkan masalah.

Menurut data di Depag Gunung Kidul, wahana wakaf tunai di Gunung Kidul sudah 
dicanangkan, hanya saja kurangnya sosialisasi kepada masyarakat muslim di Gunung Kidul, membuat wakaf tunai belum berjalan sesuai rencana. Jumlah umat Islam ada di Gunung Kidul merupakan aset besar untuk penghimpunan dan pengembangan wakaf uang. Menurut Al Arif (2010), jika wakaf tunai dapat diimplementasikan maka ada dana potensial yang sangat besar yang bisa dimanfaatkan untuk pemberdayaan dan kesejahteraan umat. Bisa dibayangkan, jika 300.000 umat Islam Gunung Kidul mau mengumpulkan wakaf tunai senilai Rp 100 ribu setiap bulan, maka dana yang terkumpul berjumlah Rp 300.000.000 setiap bulan (3,6 milyar setahun). Jika diinvestasikan dengan tingkat return 10 persen per tahun maka akan diperoleh penambahan dana wakaf sebesar Rp 30 juta setiap bulan (Rp 360 juta) per tahun. Dalam beberapa tahun, maka Gunung Kidul akan bebas dari kemiskinan. Lebih lanjut, Fanani, (2011) menyatakan bahwa pengelolaan dana wakaf tunai di Indonesia, amat memungkinkan untuk diimplementasikan, yang harus segera dilakukan adalah, sosialisasinya ke masyarakat. Jika sosialisasi mengenai wakaf tunai ini berhasil maka, permasalahan permodalan bagi para TKW purna yang memiliki intensi kuat berwirusaha dapat diselesaikan. Untuk mewujudkan hal ini, tentu saja membutuhkan kerjasama yang baik dari berbagai aspek, yaitu dinas terkait, tokoh masyarakat, individu yang ingin mewakafkan dananya maupun mereka yang perlu dibantu agar terlepas dari jerat kemiskinan.

Menurut Chamid, (2009) peran pemerintah sebagai pemimpin umat, amat dibutuhkan dalam mewujudkan kemandirian ekonomi. Salah satu upaya yang harus dilakukan yaitu dengan membuka akses peluang permodalan bagi mereka yang berminat untuk berwirausaha. Selain itu, pelatihan dan pendampingan usaha juga perlu dilakukan oleh pemerintah melalui dinas terkait. Dalam konteks pemanfaatan wakaf tunai untuk kemandirian ekonomi, peran pemerintah adalah membuat aturan atau regulasi yang jelas, sehingga dapat dijadikan acuan bagi para pelaksananya.

\section{SIMPULAN DAN SARAN Simpulan}

Beberapa simpulan yang dapat di- ambil dari penelitian ini adalah sebagai berikut: (1) Hasil analisis data menunjukkan bahwa terdapat korelasi parsial dari variabel kepribadian, lingkungan dan demografi terhadap intensi kewirausahaan para TKW purna di Kabubaten Gunung Kidul. Dari ketiga variabel tersebut korelasi terbesar ada pada variabel lingkungan; (2) Secara simultan menunjukkan adanya korelasi dari variabel kepribadian, lingkungan dan demografi terhadap intensi kewirausahaan TKW purna di Kabupaten Gunung Kidul. Meskipun demikian kontribusi dari ketiga variabel terhadap intensi hanya sebesar 23,3\%, sedang sisanya dipengaruhi oleh variabel lain; (3) Pengujian hipotesis parsial menunjukkan bahwa dari ketiga variabel bebas, hanya variabel lingkungan yang berpengaruh secara signifikan terhadap minat dan bakat kewirausahaan TKW purna diKabupaten Gunung Kidul. Dua variabel yang lain, yakni kepribadian dan demografi masing-masing secara parsial tidak berpengaruh signifikan terhadap intensi kewirausahaan TKW purna di Kabupaten Gunung Kidul.

\section{Temuan dalam penelitian}

(1) Para TKW purna di Gunung Kidul Yogyakarta adalah wanita, sebagian besar berusia di atas 40 tahun, (70\%) mereka mendapat pengetahuan kewirausahaan dari pelatihan atau pendidikan, namun tidak memiliki pengalaman dalam berwirausaha; (2) Sebesar 55,7\% alasan bekerja ke luar negeri karena desakan ekonomi dan sebesar 51,7\% karena kurang ketersediaan lapangan kerja di wilayah Gunung kidul dan sisanya karena memang sebagai pencari nafkah utama serta karena mencari modal usaha; (3) Terdapat potensi sumber permodalan yang bisa dilakukan yaitu dengan menggunakan dana wakaf tunai; (4) Terdapat potensi dana 
wakaf tunai yang cukup besar di Kabupaten Gunung Kidul.

\section{Saran}

Berdasarkan hasil penelitian, maka dapat diberikan beberapa saran sebagai berikut: (1) Perlu adanya tindak lanjut dengan memberikan pelatihan kewirausahaan bagi para TKW purna mengingat adanya intensi kewirausahaan, sehingga dapat dibentuk suatu lingkungan usaha yang semakin meningkatkan kemauan berwirausaha. Lingkungan usaha perlu di bentuk, mengingat variabel inilah yang memiliki pengaruh paling kuat diantara variabel lainnya, terhadap intensi kewirausahaan para TKW purna di Kabupaten Gunung Kidul; (2) Untuk penelitian selanjutnya, perlu dilakukan analisis intensi kewirausahaan dengan menggunakan variabel lainnya.

\section{Saran Berdasarkan Temuan Penelitian}

(1) Perlu dibentuk suatu model kerjasama kemitraan atau koperasi di lingkungan para mantan TKW sehingga semangat dan implementasi kemandirian ekonomi dapat berkembang luas; (2) Perlu adanya kerjasama lintas departemen (Dinsoskertrans dan Dinas Kementrian Agama) untuk mengatur regulasi pemberdayaan kemandirian ekonomi, melalui kewirausahaan; (3) Pemerintah daerah Gunung Kidul, melalui Dinsoskertrans diharapkan membuka kesempatan wirausaha dengan banyak membuka peluang usaha; (4) Pemerintah daerah Gunung Kidul melalui dinas Kementrian Agama, juga diharapkan segera membuat mekanisme penyaluran bantuan modal dari wakaf tunai yang memiliki potensi cukup besar di Gunung Kidul.

\section{DAFTAR PUSTAKA}

Al Arif, M. N. R. 2010. Potensi Wakaf Uang Serta Dampaknya Terhadap Perekonomian. Jurnal Dialog Balitbang Kemenag RI 70: 14-23.

Aliasuddin. 2002. Zakat atas Tabungan. Mon Mata: Jurnal Ilmu-ilmu Sosial Bidang Ekonomi 4(2): 89-100.
Amari, F. dan I. Abbes. 2014. The Influence of Individual Factors The Entrepreneurial Intention. International Journal of Managing Value and Supply Chains (IJMVSC) 5(4): 47-57.

Arikunto, S. 2006. Prosedur Penelitian Suatu Pendekatan Praktek. PT Renika Cipta. Jakarta.

Ajzen, I. 2006. From Intentions to Actions: a Theory of Planned Behavior. J. Kuhl and J. Beckmann (Eds), Action Control: From Cognition to Behavior. Springer-Verlag. NY: 11-39. New York.

Badan Pusat Statistik Indonesia. 2007-2013. BPS. Jakarta.

Bapeda Gunung Kidul, Program Pemberdayaan Ekonomi Masyarakat, 2014. Bisnis Indonesia Edisi 16 oktober 2008, http://www.bisnis.com.

Budiati, Y., T. E. Yani, dan N. Universari. 2012. Minat Mahasiswa Menjadi Wirausaha (Studi Pada Mahasiswa Fakultas Ekonomi Universitas Semarang). Jurnal Dinamika Sosial Budaya 14(1): 89-100.

Chamid, N. 2009. Membangun Masyarakat Madani: Upaya Mendukung Pemberdayaan Basic Sistem Ekonomi Islam Menurut Ibnu Khaldun Economic Model. Jurnal Empirisima 18(1): 101-112.

Cheraghi, M. dan T. Schott. 2015. Education and Trainning Benefiting a Career as Entrepreneur Gender Gaps and Gendered Competencies and Benefits. International Journal of Gender and Entrepreneurship 7(3): 321-343.

Fanani, M. 2011. Pengelolaan Wakaf Tunai. Walisongo Jurnal Penelitian Sosial Keagamaan 19(1): 179-195.

Friedrichs, Y. V. dan O. Wahlberg. 2016. Social Entrepreneurship In The Rural Areas-a Sports Club's Mobilisation of People, Money and Social Capital. International Journal of Entrepreneurship and Small Business (IJESB) 29(2): 199-216.

Gamal, M. 2007. Sedekah Dalam Perspektif Pemberdayaan Ekonomi Umat. http:// www.kabarindonesia.com/berita.php? pil=2 $0 \mathcal{E} j d=$ Sedekah+Dalam + Perspektif + Pember 
dayaan+Ekonomi+UmatEdn=2007032119 0638. Diakses Tanggal 12 Oktober 2016.

Ghozali, I. 2006. Statistik Non Parametrik. Badan Penerbit UNDIP. Semarang.

Indarti, N. dan R. Rokhima. 2008. Intensi Kewirausahaan Mahasiswa: Studi Perbandingan Antara Indonesia, Jepang, dan Norwegia. Jurnal Ekonomika dan Bisnis Indonesia 23(4): 1-27.

Indrijatiningrum, M. 2005. Zakat Sebagai Alternatif Penggalangan Dana Masyarakat Untuk Pembangunan. Jurnal Ekonomi Keuangan dan Bisnis (EKSIS) $1(4)$.

Kolvereid, L. 1996. Prediction of Employment Status Choice Intentions. Journal of Entrepreneurship Theory and Practice 21(1): 47-57.

Kristiansen, S., B. Furuholt, dan F. Wahid. 2003. Internet Cafe Entrepreneurs: Pioneers in Information Dissemination in Indonesia. The International Journal of Entrepreneurship and Innovation 4(4): 25126.

Krueger, N. F., M. D. Rielly, dan A. L. Casrud. 2000. Competing Model Of Entrepreneurial Intentions. Journal of Business Venturing 15(5): 411-432.

Lestari, R. B. dan T. Wijaya. 2012. Pengaruh Pendidikan Kewirausahaan Terhadap Minat Berwirausaha Mahasiswa di STIE MDP, STIMIK MDP, dan STIE MUSI. Jurnal Ilmiah STIE MDP 1(2): 112-119.

Morello, V. L., D. Deschoolmeester, dan E. A. Garcia. 2003. Entrepreneurial Intention of Undergraduates at ESPOL in Equador. CICYT-ESPOL.

Mughnisani, F. 2015. Pengelolaan Wakaf Tunai di Yayasan Wakaf Umi. Jurnal Istisaduna 1(1): 72-80.
Oosterbeek, H., M. Van Praag, dan A. Ijsselstein. 2008. The Impact of Entrepreneurship Education On Entrepreneurship Competencies and Intentions: an Evaluation of the Junior Achievement Student Mini-Company Program. Tinbergen Institute Discussion Paper No. TI 2008-038/3.

Ozaralli, N. dan N. K. Rivenburgh. 2016. Entrepreneurial Intention: Antecedents to Entrepreneurial Behavior in The USA and Turkey. Journal of Global Entrepreneurship Research. 6(3). DOI: 10.1186/ 540497-016.0047.

Qureshi, M. S., S. Saeed, dan S. W. M. Wasti. 2016. The Impact of Various Entrepreneurial Interventions During The Business Plan Competition on the Entrepreneur Identity Aspirations of Participants. Journal of Global Entrepreneurship Research 6(1): 9. DOI: 10.1186/540497-016-0052.0.

Sarwono, E. 2011. Kajian Empiris Entrepreneur Intention Mahasiswa. Jurnal Ekonomi Bisnis 16(2): 128-130.

Sinha, T. N. 1996. Human Factors in Entrepreneurship Effectiveness. The Journal of Entrepreneurship 5(1): 23-29.

Suharti, L. dan H. Sirine. 2011. Faktor-Faktor yang Berpengaruh Terhadap Niat Kewirausahaan (Entrepreneurial Intention): Studi Terhadap Mahasiswa Universitas Kristen Satya Wacana. Jurnal Manajemen dan Kewirausahaan 13(2): 124134.

Utami, A. F. dan I. Munawar. 2014. Implementasi Pengelolaan Wakaf Tunai (Studi Pada Baitul Maal Hidayatullah dan Yayasan Dana Sosial Al-Falah). Jurnal Ilmiah Mahasiswa FEB Universitas Brawijaya 3(1). 